\title{
The Fusion of Competence and Integrity Problems in Transformation of Public Human Resources Management Model
}

\author{
Dahlan $^{1}$, Fatmawada ${ }^{2}$ \\ Institut Ilmu Sosial dan Ilmu Politik Yapis Biak Papua \\ Email: ellanglan@yahoo.co.id
}

(Received: May 15-2019; revised: Juny 10-2019; published: December 31-2019)

\begin{abstract}
The limited quality of human resource management in the Biak Numfor Regency in Papua requires fundamental transformation. Based on available data, the determinants that reject the transformation process include two categories, namely, lack of competence and integrity. This study uses a postpositivistic interpretive phenomenological philosophy that emphasizes the meaning and descriptive process to understand the process of transformation. Local government leaders who are not trustworthy in applying the concept of human resource management based on the Cakar thesis latently significantly affect the integrity of the domestic apparatus. That has an impact on the lack of credibility of the Biak Regional Human Resources Development Agency. In short, increasing the competency of human resources as an effort to produce adequate human resources in this region becomes an important key for successful transformation.
\end{abstract}

Keywords: Competence, Integrity, and Transformation of HRM Model

\section{INTRODUCTION}

The credibility of the managers of human resources (HR) in developing the quality of the apparatus in Indonesia has drawn criticism (Arndt, 1975; van Dijk \& Szirmai, 2006). In the network of government organizations, criticism is directed at agencies, fields or parts of HR which are still commonly identified with mere personnel administration issues, and are only played marginally in controlling the strategic direction of the organization (Arndt, 1975; Nomura, 2009; Wihantoro, Lowe, Cooper, \& Manochin, 2015). Therefore, the HR department is less viewed as an equal partner by other fields or sections in moving the direction of the organization (Akib, Guntur, \& Salam, 2016; Ismail, Sulur, Akib, \& Salam, 2016; Said, Salam, Akib, \& Baharuddin, 2017).

This reality happens in the network of government organizations in Indonesia today. To reverse this kind of situation, there are at least two strategic steps to improve the internal self of HR managers that need to be confirmed and practiced immediately. This strategic step will enable the apparatus of HR managers to adapt to the organization's strategic environment and conceptual options that allow it to be practiced in an organizational climate where managerial structures and functions still tend to be rigid. Kwon (2009) emphasis on the urgency and relevance of human capital strategies in the management of HR management is very relevant in this regard.

First, every public HR manager must understand the sectoral dynamics they are working in (Harris Mulvaney, Zwahr, \& Baranowski, 2006; Hiltrop, Despres, \& Sparrow, 1995; Saidi, Mansor, Anvari, \& Hassan, 2014; Shukla, 2014; Zhang \& Nesbit, 2018). At least know the 
186| Jurnal Ilmiah Ilmu Administrasi Publik: Jurnal Pemikiran dan Penelitian Administrasi Publik

Volume 9 Number 2,July - December 2019. Page 185-190

position of the organization in the competition map and be able to read the direction of future development. It is time for public organizations to delve into the meaning of competition because a few public goods and services have been managed through public service agencies that receive their income directly from the public (market) in competition with operators of public goods services of the private sector. The apparatus HR managers are still stuttering and have not yet mastered the dynamics of the sector's development in their fields or also about the configuration of future competition. Even many of them do not know the achievement/performance of services and other competitors' innovations on the market share of public goods and services that they manage.

Second, equip yourself with a solid understanding of various concepts and practices of right HR management. The apparatus HR managers must be able to formulate and realize an HR development strategy that is integrated with the needs of the organization. In this case, HR managers must be able to understand and be able to apply various methods of HR development on target. But the facts prove, with the knowledge that is not yet solid and comprehensive, the apparatus HR managers have not been able to find the right settings for the implementation of the human capital strategy in the structural constellation and managerial functions of the organization formed by the current regulations.

This phenomenon is illustrated in the research of Simon, Mas' ud, \& Su'un (2016) who found that core competence is one of the empirical categories that become the weakness of the apparatus in the adaptation and implementation of conceptual models into the operation and implementation of the tasks and functions of public organizations. Resolving the problem of apparatus competency is the key to the ability of public organizations to transform the implementation of human resource management that adapts the human capital strategy in it. Conversely, without the transformation of the management of apparatus HR management, public organizations will increasingly be marginalized in competition and will continue to be pressured in the increasingly progressive constellation of society.

Regarding the urgency and relevance of human capital strategy adaptation in the management of apparatus human resources, a prospective data presented by Gamerschlag, (2013) is very appropriate for that in 1975, the contribution of intangible assets to the success of an organization was only 17\%. But in 2015 it had reached $84 \%$. Intangible assets are all human potential as organizational resources, which are used as indicators of measurement of a human capital strategy in the implementation of human resource management. In the context of the current challenges, the management of public human resources will considerably require the role of human capital strategies in increasing the professional competence (intangible assets) of the apparatus in order to achieve organizational goals and objectives.

In the turmoil of the problems of public organizations, there is a great responsibility to provide quality services to the community that will only be possible if supported by professional and competent apparatus resources. For this purpose, the plan for the development of HR for professional apparatuses has been set out in a visionary manner in Presidential Regulation No. 81 of 2010 concerning the Grand Design of the 2010-2025 Bureaucracy Reform. Some related laws to support this vision have also been issued, such as Law Number 25 of 2009 concerning 
Public Services, whose substance mandates the competence and professionalism of the apparatus.

The variety of policies that have been present mandating and supporting the transformation process of the HR management of the apparatus are a few facts besides other factual issues that is, there is no significant change in public HRM practices. This is a phenomenon that presents its own interference value for public HR research. Although it must also be acknowledged that there are a small number of regional governments that have demonstrated their efforts in organizing part by part of their organizations in order to create professional and competent apparatuses.

\section{METHOD}

Data collection is done through interview techniques to obtain primary data. Secondary data collected through observation techniques and document review. The primary data sources are from the following informants, including (1) one Head of the Human Resources and Human Resources Development Agency of Biak Numfor Regency; (2) one Secretary of the Regional Human Resources and Human Resources Development Agency of Biak Numfor Regency; (3) one Head of Employee Development; (3) one Head of Employee Mutation Division; (4) one Head of the Education and Training Apparatus Division; (5) one Head of Employee Data and Information Division; (6) one Head of Planning and Procurement Sub-Division; (7) one Head of Position and Mutation Position Sub-Division; (8) one Head of Program Preparation Subdivision; (9) one Head of Finance Sub Division; (10) one Head of General Subdivision; (11) five program implementers.

Regular informants are all employees within the scope of the Regional Human Resources and Human Resources Development Agency of Biak Numfor Regency who have the potential to provide the necessary information and data. Secondary data sources are sources of supporting data needed to complete the primary data collected. This is done as an effort to adjust to the needs of field data related to the focus being studied.

\section{RESULT AND DISCUSSION}

Based on the preliminary document review, what is conceptually called by Pakar (2003) as the 'formulation of HRM strategy', has been outlined in the Biak Numfor District BKD Strategic Plan document for 2016-2021. Although it seems clear that it does not show cohesion, but the objectives of the organization and various main processes in the organization have been determined.

On that basis, the capabilities of the apparatus have been calculated and established (establishing current capabilities). The boundaries of objective activities, which are attached later to the strategy to be used in connection with the needs and objectives of the regional HRM are also established. However, the setting of human resource policy activities still includes traditional aspects, not yet indicating a continuous performance evaluation method, forming a training scheme and apparatus development. This is evident in the series of indicative and implemented program activities. 
188 Jurnal Ilmiah Ilmu Administrasi Publik: Jurnal Pemikiran dan Penelitian Administrasi Publik Volume 9 Number 2,July - December 2019. Page 185-190

With the factual data on the formulation of the HRD Strategy of BKD in Biak Numfor Regency, the prospect that is expected to take place optimally is the stage of implementing the HRM strategy that has become the area's formulation as a form of consistency and innovation transformation in the management of regional human resources. Including in this case, how the process of organizing HRM Human Resources and Human Resource Development Agency of Biak Numfor Regency is monitoring the impact of the results achieved by the organization related to the HR management strategy applied.

Cakar's thesis of thought (2003) interpreted into the reality of the implementation of HRM in Biak Numfor Regency moved through the assumption that there is still a set of factual problems in this area as a factor that weakens the application of HRM even though it seems clear the desire and efforts to make changes. As with the wide range background in the opening of this discourse, the fact that the units and employees who manage this area of HR and the implementation of competency-based HR management must be considered must be considered. Don't even have the expertise needed. The commitment of the parties in the organization in the framework of implementing competency-based HR management must still be considered. To get out of the situation, shortcuts to submit competency-based HR management programs and activities, entirely to external consultants, are also not implemented. Of course, it is necessary to consider the budgeting and software needed to support the apparatus competency management data.

The use of the theoretical tool Hamdan (2015) clearly helped the effort to identify and analyze the factual conditions of the transformation of the regional HR management model in Biak Numfor. Based on available data, the factual issues surrounding the transformation process revolve around two problem categories namely, the problem of knowledge of the regional apparatus HR manager as the first category and the integrity problem as the second problem category.

The competence of regional apparatus HR managers in Biak is still not solid, resulting in HR managers still tend to work with the automation of work habits that have taken place as long as this. Especially related to how to create novelty in the Biak apparatus HR management model by shifting the theoretical categories of HRM into the daily work. This analysis is in line with the findings of Simon et al., (2016) which states that core competence is one of the empirical categories that becomes the weakness of the apparatus in the adaptation and implementation of conceptual models into the operation and implementation of the tasks and functions of public organizations.

\section{CONCLUSION}

The competency issue lately colors the integrity of the HR management of the regional apparatus in Biak. Powerlessness then becomes a strong characteristic of the inability of the way the field of education and training of the Biak Regional Personnel Agency has been to develop the competency of the personnel managing the apparatus. This core competence further strengthens the analysis as a core problem that hinders the process of transforming the HR management model of the Biak area because in fact the HR managers state that the strategic 
development of the HR apparatus has been mandated starting from the previous staffing law. However, so far, the implementation of the Biak apparatus HR development strategy is only able to carry out education and training activities that are not based on competency assessment. HR managers are also unable to be creative in presenting knowledge packages for development, especially for HR managers. As a continuation of the results of the identification and analysis of research problems using the theoretical set of the conceptual model of Paws (2003), the right recommendation is to adapt the thesis of Lengnick-Hall \& Lengnick-Hall (2003: 33-43) which integrates all organizational matters into policy human resource management program. This perspective can help the development of apparatus HR development program policies with factual conditions in the Biak Regency.

Thus, solving the problem of apparatus competency is the key to the ability of public organizations to transform the implementation of human resource management that adapts the human capital strategy in it. Conversely, without the transformation of the management of apparatus HR management, public organizations will increasingly be marginalized in competition and will continue to be pressured in the increasingly progressive constellation of society.

\section{REFERENCES}

Akib, H., Guntur, M., \& Salam, R. (2016). Civitas Academic Perception of "Blissful Services" for Recipient Postgraduate Program State University of Makassar, Indonesia. International Conference on Public Organization VI (ICONPO VI), 340-350. Thammsat University, Tha Prachan Campus.

Arndt, H. W. (1975). Development and equality: The Indonesian case. World Development, 3(2), 77-90. https://doi.org/https://doi.org/10.1016/0305-750X(75)90039-X

Gamerschlag, R. (2013). Value relevance of human capital information. Journal of Intellectual Capital, 14(2), 325-345.

Hamdan, H. (2015). Administrative Accountability in the organization of Secondary Education Program on Education Department in Biak Numfor Regency, in the year 2014. Universitas Negeri Makassar.

Harris Mulvaney, R. R., Zwahr, M., \& Baranowski, L. (2006). The trend toward accountability: What does it mean for HR managers? Human Resource Management Review, 16(3), 431442. https://doi.org/https://doi.org/10.1016/j.hrmr.2006.06.003

Hiltrop, J.-M., Despres, C., \& Sparrow, P. (1995). The changing role of HR managers in Europe. European Management Journal, 13(1), 91-98. https://doi.org/https://doi.org/10.1016/0263-2373(94)00061-B

Ismail, A., Sulur, A. H., Akib, H., \& Salam, R. (2016). Snapshot of Society Social-Economic Welfare based on Human Development Index in Polewali Mandar Regency, Indonesia. International Conference on Public Organization VI (ICONPO VI), 847-858. Thammsat 
190| Jurnal Ilmiah Ilmu Administrasi Publik: Jurnal Pemikiran dan Penelitian Administrasi Publik Volume 9 Number 2,July - December 2019. Page 185-190

University, Tha Prachan Campus.

Kwon, D.-B. (2009). Human capital and its measurement. The 3rd OECD World Forum on "Statistics, Knowledge and Policy" Charting Progress, Building Visions, Improving Life, 27-30.

Nomura, K. (2009). A perspective on education for sustainable development: Historical development of environmental education in Indonesia. International Journal of Educational Development, 29(6), 621-627. https://doi.org/https://doi.org/10.1016/j.ijedudev.2008.12.002

Said, F., Salam, R., Akib, H., \& Baharuddin, A. (2017). An Analysis of Tourism Visit Trend. 149(Icest), 34-36.

Saidi, M. I., Mansor, N. N. A., Anvari, R., \& Hassan, M. A. (2014). Defining HR Roles of Nursing Line Manager in Workplace Learning. Procedia - Social and Behavioral Sciences, 129, 148-155. https://doi.org/https://doi.org/10.1016/j.sbspro.2014.03.660

Shukla, S. (2014). Emerging Issues and Challenges for HRM in Public Sectors Banks of India. Procedia - Social and Behavioral Sciences, 133, 358-363. https://doi.org/https://doi.org/10.1016/j.sbspro.2014.04.201

Simon, Y., Mas' ud, M., \& Su'un, M. (2016). The role of apparatus competence, internal control system on good governance and the quality of financial statement information. Researchers World, 7(4), 123.

van Dijk, M., \& Szirmai, A. (2006). Industrial Policy and Technology Diffusion: Evidence from Paper Making Machinery in Indonesia. World Development, 34(12), 2137-2152. https://doi.org/https://doi.org/10.1016/j.worlddev.2006.03.004

Wihantoro, Y., Lowe, A., Cooper, S., \& Manochin, M. (2015). Bureaucratic reform in postAsian Crisis Indonesia: The Directorate General of Tax. Critical Perspectives on Accounting, 31, 44-63. https://doi.org/https://doi.org/10.1016/j.cpa.2015.04.002

Zhang, Y. E., \& Nesbit, P. L. (2018). Talent Development in China: Human resource managers' perception of the Value of the MBA. The International Journal of Management Education, 16(3), 380-393. https://doi.org/https://doi.org/10.1016/j.ijme.2018.06.001 